\title{
Reading, Writing, Getting It Right: A Response to David Leeson's "Cutting Through History"
}

\section{Nancy Partner}

It is important to keep in mind that the essay which provoked this experiment in historical surrealism, "The Burden of History," by Hayden White was first published in 1966 which is now a long time ago. But one can make the same point about many of Hayden White's most thoughtful and important essays although the "long time ago" becomes twenty years shorter when considering the major statements on narrative collected in The Content of the Form in 1987. Still, it is worth pondering the slow ruminative process of the collective historical discipline when Hayden White's name is now known by every historian everywhere and still most commonly associated with Metahistory of 1973, his most frequently cited work with the most marginal implications for ongoing historical writing. Throughout all this time, historians have tended to read White guided by an all-enveloping willful reading error about the implicit reading instruction running through all of his work. I regularly encounter the same reading error when I assign students the book by Aristotle commonly called the Poetics. This is a book which might alternatively and accurately be titled On Fiction or On Narrative Fiction, but students, even with forceful prompting away from this error, tend to read it as How To Write A Tragedy: Rules And Guidelines For The Aspiring Author. Aristotle's book is a work of theoretical analysis which explains which elements of fictional composition are fundamental to this ant form and which are secondary, how the fundamental elements work to produce the most serious intellectual and aesthetic ends of literature, and only in the most remote educational sense can the book be considered prescriptive. The Poetics is about how the component elements of fictional narrative produce their effects when analysed in the light of serious aims, not about how to write narrative fictions following a rote "how to" guide. The difference here is important and it is a clear and distinct one.

The same distinction applies to all of Hayden White's work on historical writing: even though he sometimes drifts into a teasing assertiveness, a mischief making épater les bourgeois historians whom he, quite justifiably, textually conjures up as resistant readers, resisting his ideas, in need of a kick-start in a new direction. His essays are about how historical writing works at a deeply analysed level, not How to Write Up-To-Date History By Imitating Fiction. The brunt of White's historical theoretical project, all of it, is that historical knowledge is a written knowledge: history is that form of complex prose (either straightforwardly narrative or narrative by implication, its subject matter being time-situated by definition) whose writer/reader contract is truth- 
claim and which offers itself as an addition to knowledge of the past. Therefore, a serious understanding of history requires close scrutiny of how complex narrative prose works, at every level, to produce its truth-claim effects of representation and meaningfulness. Writing about complex events with a historical intention ("reader, this account is offered as true") has always produced narratives that are remarkably similar to contemporary fictional literature recounting similar persons and actions - epics of war and adventure, conflict in the state, heroic or saintly lives. In the pre-professional past, historians were self-educated as writers on a curriculum of admired fiction. Only with the professionalization of history within university auspices has the historian become a writer malgré lui, a writer by accident almost, an imitative writer naively or unknowingly denying his imitations. The near total neglect or deliberate ignorance of tropological language and narrative structure, anything "literary," on the part of historians which White addressed in the $1960 \mathrm{~s}$, and decades after that, tempted him to some provocative tactics in his early essays, just to jolt someone out there into paying attention. One would think that after some thirty years of the linguistic turn, historians might by now have learned to recognize rhetorical strategies for what they, rhetorically, are and not read earnest literal messages where mild shock tactics were intended.

"The Burden of History" is genuinely the term that David Leeson chooses for it - a "manifesto" addressed to a professional cadre of historians and their institutional self-perpetuation which White regards (or did in 1966) as "perhaps the conservative discipline par excellence." But this up front challenge to his historian colleagues (and it is easy to forget that White is a medieval historian by training, and speaks always as one of "us," with that special freedom) is not precisely one of "political radicalism" as Leeson insists. The conservatism White deplores is intellectual in the old large sense, a cultural conservatism of unselfconscious narrow-minded outlook, which is perfectly at home among historians of both left- and right-wing politics. The looming threat implicit in this "kind of willful methodological naivete" that informs the training and deep assumptions of historical practice is that "history itself may lose its status as an autonomous and self-authenticating mode of thought." What White wants is something very difficult, probably impossible to ask of an institutionalized practice, but that has made some improbable steps in his direction since "The Burden" was written: that historians use their historical awareness to dismantle the deep complacencies of their discipline and try to reconstitute it at "a higher kind of intellectual inquiry," closer both to art and to science, and yet without giving up entirely on its special cultural work of producing knowledge of the past to a high standard of evidentiary rigor.

I was startled, in rereading "The Burden of History" for this commentary to find how strangely prescient White was, in some completely unexpected ways, about the "disease" of history which, in 1966 and in agreement with 
Norman O. Brown could be disdained as the very type of neurotic fixation, repetition compulsion, and destructive subservience to past and outmoded forms. The disease factor isolated here was not merely the objective persistence of oppressive institutions but "the way of looking at the world which gives to these outmoded forms their specious authority," and interiorizes submission to them - the deepest opposite to any form of liberation, personal or political. History, White charges, is thus complicit with anti-liberatory forces of every kind because its very "way of looking at the world" validates the continuity of the past, and it does this with redoubled effect in thoughtlessly adopting deeply traditional and conventional literary forms as its mode of expression.

There is something at first sympathetic and funny, but soon eye-rolling exasperating, about David Leeson's utterly silly experiments with scissors, paper-folding, and computerized cut-and-paste techniques. Inflicting random, meaningless, pointless découpage damages on conventional historical texts, he discovers (!) that the results are random, meaningless, and pointless. His choice of surrealist or Dadaist modes of art (why? when White was trying to urge historians to engage imaginatively with developments in literature contemporary with themselves?) was either deliberately silly or, more likely, a set-up to "prove" that historians don't have to pay attention to anything White has said because the results of doing so are an unintelligible mess of cut-up paper. It feels patronizing, yet embarrassingly necessary, to point out to the author that the reason that surrealism, Dadaism, cubism, impressionism, realism, etc., are modes of art is because the artists had created coherent meaningful vocabularies (visual or verbal) to express ideas which could not otherwise be conveyed. Leeson's "cut-ups" are just the author being the class cut-up. His own language betrays a tin ear and a smart-aleck's taste in discourse: "So, then: so what? I'm glad I asked: I think my cut-ups raise questions about Hayden White's whole project - that's what." The smartest guy in the sixth grade - that's what.

Turning back to White's intense and relentless critique after Leeson's smirky criticism of surrealism and Dada (again, why? and to what purpose?) and cute references to Frankenstein, one wonders what motivated this little project and its shallow, finger-flipping outrage. White was challenging historians to locate new governing metaphors to provide illumination and coherence to accounts of the past: "to entertain seriously those creative distortions offered by minds capable of looking at the past with the same seriousness as ourselves but with different affective and intellectual orientations." It is obvious that his essay is as fresh and salient now as it was when first published, and needs to be read again, and seriously this time. 